\title{
Candela Second per Square Meter
}

National Cancer Institute

\section{Source}

National Cancer Institute. Candela Second per Square Meter. NCI Thesaurus. Code C122203.

A unit of luminous intensity expressed as one candela in one second of light emittance per square meter of area. 